\title{
Vaginal Neuroendocrine Carcinoma
}

National Cancer Institute

\section{Source}

National Cancer Institute. Vaginal Neuroendocrine Carcinoma. NCI Thesaurus. Code C128073.

A rare neuroendocrine carcinoma that arises from the vagina. This category includes small cell and large cell neuroendocrine carcinoma. 